\title{
From Arctic Science to International Law: The Road towards the Minamata Convention and the Role of the Arctic Council
}

\author{
Froukje Maria Platjouw*
}

Norwegian Institute for Water Research (NIVA), Section for Water and Society University of Oslo, Scandinavian Institute for Maritime Law

\section{Eirik Hovland Steindal}

Norwegian Institute for Water Research (NIVA), Section for Water and Society

\author{
Trude Borch \\ Akvaplan-niva, Framsenteret
}

\begin{abstract}
The Minamata Convention, which entered into force on 16 August 2017, is a global, legally binding instrument on mercury. The initiative on the Minamata Convention was mainly driven by research showing negative effects on human health and the environment in the Arctic. The Arctic Council, an intergovernmental forum promoting cooperation on Arctic issues, and its Working Group, AMAP, played an important role in the process leading up to international negotiations on the Minamata Convention. This paper elucidates the evolutionary process in which scientific knowledge, herded by an intergovernmental, regional forum, is involved and forms the basis for a legally binding agreement. The paper provides new insight on multilevel governance of the mercury issue and unravels the role that AMAP has played in this dynamic process.
\end{abstract}

Keywords: Minamata Convention on mercury; science-policy interface; Arctic Council; the Arctic Monitoring and Assessment Programme (AMAP); international negotiations

Responsible Editor: Øyvind Ravna, UiT - The Arctic University of Norway, Tromsø, Norway.

Received: April 2018; Accepted: June 2018; Published: August 2018

\footnotetext{
^Correspondence to: Froukje Maria Platjouw, Froukje.platjouw@niva.no

(C) 2018 Froukje Maria Platjouw, Eirik Hovland Steindal and Trude Borch. This is an Open Access article distributed under the terms of the Creative Commons Attribution-NonCommercial 4.0 International License (https://creativecommons.org/ licenses/by-nc/4.0/), allowing third parties to share their work (copy, distribute, transmit) and to adapt it, under the condition that the authors are given credit, that the work is not used for commercial purposes, and that in the event of reuse or distribution, the terms of this license are made clear.

Citation: Froukje Maria Platjouw, Eirik Hovland Steindal and Trude Borch. "From Arctic Science to International Law: The Road towards the Minamata Convention and the Role of the Arctic Council" Arctic Review on Law and Politics, Vol. 9, 2018, pp. 226-243. http://dx.doi.org/10.23865/arctic.v9.1234
} 
This paper explores the dynamic road towards the Minamata Convention through analyzing the role of the Arctic Council (AC), mainly through its working group the Arctic Monitoring and Assessment Program (AMAP), as provider, broker and communicator of science related to the environmental problem of mercury. This first section introduces the problem of mercury in the Arctic and globally; the organization of the AC and AMAP; and the background for the Minamata Convention. The second section explores the concept of science-policy interfaces more thoroughly and discusses the possible roles of scientific experts in these interfaces. This serves as a background for the third section which provides an in-depth and concise historical analysis of science, brokered by an intergovernmental forum, and the policy interfaces on the road towards adoption of the Minamata Convention on Mercury in 2013.

\section{Introduction}

Mercury is a chemical of global concern. ${ }^{1}$ Long-range atmospheric transport, persistence in the environment once anthropogenically introduced, the ability to bioaccumulate in ecosystems and the significant negative effects on human health and the environment are the main reasons for this concern. ${ }^{2}$ Particularly in the Arctic, mercury is a severe environmental problem. ${ }^{3}$ As most of the mercury in the region is long-transported, international action is needed.

In many Arctic organisms, levels of mercury concentrations are higher than elsewhere. Most of the mercury that arrives in the Arctic is carried by the prevailing winds, ocean currents and rivers. ${ }^{4}$ Once the mercury reaches the Arctic, it spreads throughout the physical and biological systems that make up the Arctic environment. The rate and extent at which this happens is dependent on the different chemical forms in which mercury exists, the physical and chemical processes involving mercury that dominate each system, and a wide range of climatic, geochemical, biological and environmental factors. ${ }^{5}$ The 2008 Global Atmospheric Mercury Assessment by UNEP estimated that mercury levels in the Arctic air can on occasion be five to fifty times higher than levels measured in Europe and North America. ${ }^{6}$

Mercury has the ability to bioaccumulate and biomagnify in food webs. Living organisms readily take up mercury from their environment (either directly from air or water or by eating food containing mercury), with levels of mercury generally increasing with each step up the food chain. Typically, mercury levels are two to seven times higher at each successive step in a food chain. ${ }^{7}$ The ubiquity of mercury in the Arctic ecosystem, the biomagnification in the food web and the potential effects on the organisms higher up in the food web, is a major challenge. Indigenous peoples are particularly vulnerable as they rely on subsistence hunting and fishing. Part of their traditional diet may contain high levels mercury and other contaminants, with potential interacting effects. ${ }^{8}$

Much of the scientific knowledge on the problem of mercury has been processed and communicated by the Arctic Council (AC) and its working group the Arctic 


\section{Froukje Maria Platjouw, Eirik Hovland Steindal and Trude Borch}

Monitoring and Assessment Program (AMAP). The AC is the leading intergovernmental forum promoting cooperation, coordination and interaction among the Arctic States, ${ }^{9}$ Arctic indigenous communities and other Arctic inhabitants on common Arctic issues, in particular on issues of sustainable development and environmental protection in the Arctic. ${ }^{10}$ The AC consists of eight Arctic States members, as well as six organizations with Permanent Participant status representing Arctic indigenous peoples. The category of Permanent Participant was created to provide for active participation and full consultation with Arctic indigenous peoples within the Council. Observer status in the AC is open to non-Arctic states, along with inter-governmental, inter-parliamentary, global, regional and non-governmental organizations based on an AC consideration of willingness, suitability and capability based on certain criteria defined by the Council.

The work of the AC is primarily carried out in six Working Groups, of which the Arctic Contaminants Action Program (ACAP) and AMAP have worked most actively on pollution issues. AMAP monitors the Arctic environment and human populations by synthesizing scientific research, and provides scientific advice to support governments on issues such as pollution and adverse effects of climate change. ACAP, on the other hand, was established to address the pollution issues and sources identified by AMAP. It is intended to act as a strengthening and supporting mechanism to encourage national and international action to reduce emissions and releases of hazardous chemicals.

Particularly AMAP has played a significant role in providing reliable and sufficient information on the status of, and threats to, the Arctic environment. By analyzing and synthesizing scientific data, and managing and coordinating research projects, this working group provides key scientific advice on the issue of mercury. This information has been made available to governments both within and outside the AC, facilitating the identification and implementation of relevant action to prevent and remediate contamination. The scientific knowledge provided by AMAP has been an important driver for policy and legislation on mercury, both nationally and internationally, most importantly the Minamata Convention on Mercury.

The Minamata Convention on Mercury is a global treaty to protect human health and the environment from the adverse effects of mercury. It was agreed at the fifth session of the Intergovernmental Negotiating Committee on mercury in Geneva, Switzerland, on 19 January 2013, and adopted later that year on 10 October 2013 at a Diplomatic Conference (Conference of Plenipotentiaries) held in Kumamoto, Japan. The Convention entered into force on 16 August 2017.

The Convention draws attention to a global and ubiquitous metal that occurs naturally, has a broad range of uses in everyday objects and is released to the atmosphere, soil and water from a variety of sources. Controlling the anthropogenic releases of mercury throughout its lifecycle has been a key factor in shaping the obligations under the Convention. ${ }^{11}$ The main objective of the Convention is to protect human health and the environment from anthropogenic emissions and releases 
of mercury and mercury compounds, and it sets out a range of measures to meet this objective. ${ }^{12}$ These include measures to control the supply and trade of mercury, including setting limitations on certain specific sources of mercury such as primary mining, and to control mercury-added products and manufacturing processes in which mercury or mercury compounds are used, as well as artisanal and small-scale gold mining. The text of the Convention includes separate articles on emissions and releases of mercury, with controls directed at reducing levels of mercury while allowing flexibility to accommodate national development plans. ${ }^{13}$

Major highlights of the Minamata Convention include a ban on new mercury mines, the phase-out of existing ones, the phase-out and phase down of mercury use in a number of key products and processes, control measures on emissions to air and on releases to land and water, and regulation of the informal sector of artisanal and small-scale gold mining. The Convention also addresses interim storage of mercury and its disposal once it becomes waste, sites contaminated by mercury as well as health issues. ${ }^{14}$ Despite these major highlights, the Convention also contains a number of challenges. For example, the Convention leaves a considerable degree of flexibility to Parties with regard to mercury emissions and releases. ${ }^{15}$ Though the development and adoption of the Convention is undoubtedly a major achievement, it is still unclear to what extent the provisions of the Convention, will contribute to tackling the problem of mercury. ${ }^{16}$ However, the extent to which the design and substance of the Convention is sufficient in light of the severity and complexity of the mercury problem falls outside the scope of this paper.

Instead, this paper aims to shed light on the role of the AC and particularly the AMAP working group as a science broker on the road towards adoption of the Minamata Convention. The process of generating scientific knowledge and scientific advice on a particular environmental problem leading towards a global legally binding agreement is not a straightforward one. To a large extent the pathway towards the Minamata Convention has been shaped through important science-policy interfaces, where the AC and its working group AMAP have been heavily involved. Scientific experts, linked to both AMAP as well as national delegations, have influenced the negotiating history and final text of the Minamata Convention. In an effort to elucidate the role of the AC and particularly AMAP as a science broker on the road towards the Minamata Convention, this paper identifies and describes particular science-policy interfaces in the period between 1989 and 2013.

\section{Science-policy interfaces and the role of scientific experts}

The pathway from science to policy is not straightforward. One reason for this is the fact that science never operates in a vacuum; political considerations may, for instance, put weight on one part of the research findings, guide the establishment of research programs and determine the allocation of funding. Within the scientific community, there are often multiple views or controversies over issues. Moreover, stakeholders 


\section{Froukje Maria Platjouw, Eirik Hovland Steindal and Trude Borch}

outside the scientific community may not agree with the scientific advice given, and contest the scientific knowledge base. This could be the case if scientists recommend restrictions on commercial activities for political decision-making by setting limits for carbon emissions or other environmental pollutants, such as mercury.

Despite the potential complexity and dynamic nature of the pathway towards policy and law, it is generally acknowledged that science is an important source of authority in environmental policy, and that environmental policy should be based on sound scientific findings. ${ }^{17}$ According to Bocking 2004, science enables the mapping of biological diversity and ecosystem qualities, and can thereby identify the state of ecosystems. Through this mapping, scientists can define reference points through which changes in ecosystem functioning can be monitored and communicated. As such, scientists play a central role in identifying emerging environmental hazards. ${ }^{18}$ Gluckman, however, questions how we can ensure the effective role of science in public policy-making. He argues that "[e]vidence is often contested and the policy responses are incremental at best. But policy-makers, too, are vexed by scientists' ability to identify problems, yet frequent inability to place their work in the context of timely and feasible policy solutions". ${ }^{19}$

More recently however, the role of scientific experts appears to have expanded from identifying environmental problems towards influencing the policy processes addressing these problems. In policy processes there is thus a growing reliance on experts, a process referred to as 'expertisation'. Scientific experts, rather than political and/or administrative staff, are increasingly involved in preparing policy negotiations, ${ }^{20}$ though their degree of involvement may vary. ${ }^{21}$ Scholars have identified different categories of experts, including: the pure scientist, the science arbiter, the issue advocate, and the honest broker of policy alternatives. ${ }^{22}$

Spruijt et al explain that the pure scientist seeks to focus only on facts and does not interact with decision-makers. The science arbiter answers specific factual questions posed by decision-makers. The issue advocate goes further and seeks to reduce the range of choices available to decision-makers by promoting one specific solution. The honest broker of policy alternatives seeks to expand or at least clarify the range of choices available to decision-makers. ${ }^{23}$ There are thus different dimensions of science-policy interfaces, which generally can be defined as social processes which encompass relations between scientists and other actors in the policy process, and which allow for exchanges, co-evolution, and joint construction of knowledge with the aim of enriching decision-making. ${ }^{24}$

In a literature review on the subject of (factors that influence) the roles of scientists when advising policy makers on complex issues, Spruijt et al conclude that research on expert roles has remained mostly theoretical, and they call for more empirical research. More knowledge on this issue may ultimately lead to an improved uptake of scientific information in policy processes and possibly to more effective and accepted policy measures. ${ }^{25}$ In an attempt to contribute to the need for more empirical research, this paper aims to unravel science-policy intersections and the 
role of AMAP as a science broker on the road toward adoption of the Minamata Convention.

\section{The road to Minamata - AMAP as a science broker}

This section provides an analytical and historical overview of the science-policy interfaces leading toward adoption of the Minamata Convention in 2013. The overview covers the period 1989-2013.

\subsection{An Arctic forum with growing global reach (1989-2001)}

In January 1989, the Finnish government reached out to the other Arctic states proposing a conference on the protection of the Arctic environment. ${ }^{26}$ Following discussions between the eight states, the Arctic Environmental Protection Strategy (AEPS) was adopted in June 1991. This multi-lateral, non-binding agreement encompasses issues such as monitoring, assessment, conservation, protection, emergency preparedness and response within the Arctic zone. ${ }^{27}$ As part of the strategy, it was decided to set up an Arctic Monitoring and Assessment Program (AMAP), a task force with a secretariat situated in Norway. AMAP was established to implement key elements of the AEPS by "providing reliable and sufficient information on the status of, and threats to, the Arctic environment, and providing scientific advice on actions to be taken in order to support Arctic governments in their efforts to take remedial and preventive actions relating to contaminants". ${ }^{28}$

In 1996, through the Ottawa Declaration, the AEPS-countries formally established the Arctic Council (AC) as an intergovernmental forum for cooperation, coordination and interaction among the Arctic states. ${ }^{29}$ The forum included Arctic indigenous communities and other Arctic inhabitants and focused on common Arctic issues, in particular on sustainable development and environmental protection in the region. AMAP, established five years earlier, was at the same time integrated as a working group under the AC, along with the groups: Conservation of Arctic Flora and Fauna (CAFF); Protection of the Arctic Marine Environment (PAME); and Emergency Prevention, Preparedness and Response (EPPR). ${ }^{30}$ The first AMAP assessment report was published in 1997 in a concise policy format "Arctic Pollution Issues: A State of the Arctic Environment Report". The following year, in 1998, a comprehensive, technical and fully-referenced scientific version of the same report "AMAP Assessment Report: Arctic Pollution Issues" was published. ${ }^{31}$ The report compiled existing knowledge on pollution in the Arctic, and contained a separate chapter on heavy metals, including mercury. It included several policy recommendations for the AC member states:

- Reduce domestic emissions and releases

- Complete the negotiations on the three protocols under the Convention on Long-range Transboundary Air Pollution (LRTAP Convention), including one on heavy metals 


\section{Froukje Maria Platjouw, Eirik Hovland Steindal and Trude Borch}

- Promote extension of the geographic area covered by LRTAP to include more than the European Monitoring and Evaluation Program (EMEP) area

- Strongly support the work of the INC to prepare a legally binding global agreement on POPs (later to become the Stockholm Convention)

- Explore "other appropriate mechanisms" to address and control releases of heavy metals to the aquatic and terrestrial environment, including "other legal mechanisms".

- Strive for implementation of all relevant agreements that aim at reducing pollution of the Arctic environment.

The lack of a legal instrument on heavy metals targeting transboundary pollution from all relevant sources was becoming more and more evident. Hence, one conceivable interpretation of these policy recommendations could be that "other legal mechanisms" was pointing at a global legislative measure that worked beyond current national and regional legislative frameworks, covering all relevant types of sources, emissions and releases, i.e. the early traces of a future Minamata Convention.

According to AMAP, the information provided in the first assessment report (1997/1998), was an important contribution to the negotiation of the two protocols on persistent organic pollutants (POPs) and heavy metals, for the United Nations Economic Commission for Europe's Convention on Long-range Transboundary Air Pollution. ${ }^{32}$ Besides, as an important source of information documenting contaminants transported long-range and accumulating in the Arctic, the information fed into the development of a global agreement on POPs, to be established in 2001 (Stockholm Convention).

These reports were also the foundation for the decision of the AC to cooperate to make concrete pollution reductions within the region: hence a new working form was established. The Arctic Council Action Plan to Eliminate Pollution of the Arctic (ACAP) was set up in 2000 to address sources that had been identified through AMAP. $^{33}$

Following up on its first assessments of environmental pollution in the Arctic, the AC asked AMAP to sustain its activities and update the assessment on various issues, including heavy metals and mercury. Thus, in October 2002 AMAP published its second assessment report (State of the Art), covering multiple pollution and health issues, including mercury. The report included policy recommendations stating that reducing exposure to mercury warrants regional and global action. Furthermore, it underlined that Arctic concerns must be adequately addressed in any action "undertaken by UNEP and its possible proposals". ${ }^{34}$

\subsection{Legally binding or voluntary approach - the influence of the Arctic Council and AMAP (2001-2010)}

During the period between 2001 and 2009, several key developments and initiatives took place that had a pivotal role for the development of what would later become 
the Minamata Convention. The role of the AC - through its working group AMAP changed noticeably during the period, from simply being a supplier of Arctic data and knowledge to being a key data supplier, coordinator and broker of scientific knowledge.

This changing role of the AC is not merely evident in the context of mercury. In general, the AC and AMAP became much more active in this period through a focus on large scale scientific assessments. Koivurova, Kankaanpää and Stępién (2015) argue that " $[\mathrm{t}]$ he role that has gradually evolved as a core task of the Arctic Council is its work to increase knowledge about the circumpolar Arctic to influence both national and international policy-making. The valuable outcome is the wealth of science-based information in various formats and the established capacity to compile it for different needs" ${ }^{35}$ Through these large-scale scientific assessments, the AC could influence the evolution of regional and global international environmental policies and treaties. To illustrate, in the context of persistent organic pollutants (POPs), Arctic science has been imperative. The extensive 'State of the Arctic Environment Report' from 1997, defined POPs (in addition to mercury) as an environmental and human threat, ending up in the Arctic from southern industrial regions via prevailing northerly winds and ocean circulation. To address the POPs issue, some AC member states increasingly engaged to influence global levels of governance, through active development of assessments and collaborations with UNEP. ${ }^{36}$ Whether this was a consensus based strategy from the AC or more a result of the AMAP secretariat's rather independent, proactive role, remains unclear. The AC thus joined forces to combat POPs at the regional and global levels, and data from AMAP continues to inform the global regime on these pollutants. ${ }^{37}$ In the context of POPs, Rottem (2017) illustrates how Arctic science has been important in the nomination of new POPs to the Stockholm Convention, and more particularly how Norway has acted as a green ambassador by contributing actively to the nomination process. ${ }^{38}$

Regarding mercury, Norway has taken a proactive role. Interestingly, the proactive line of the AC was more consistent with the policies and interests of the Nordic AC member countries, than with those AC members that opposed a legally binding approach. Norway was one of two countries to propose a legally binding instrument on mercury. ${ }^{39}$ This proposal was soon supported by the EU, where the other Nordic countries were particular supportive. Later even Russia joined in. The US and Canada, on the other hand, opposed the proposal during this period. Were the concurring interests of the AC and the proactive Nordic AC-members simply coincidental or rather a showcase of strategic and multilevel governance craftsmanship?

\subsubsection{1-2003}

In 2001, the UNEP Governing Council (GC) requested that the Executive Director of UNEP should undertake a global mercury assessment (GC decision 21/5), to be presented to the GC at its 22 nd session in $2003 .{ }^{40}$ Building on contributions from 


\section{Froukje Maria Platjouw, Eirik Hovland Steindal and Trude Borch}

Governments, intergovernmental and non-governmental organizations and the private sector, the report should encompass sources, environmental fate, health effects, prevention measures and control technologies. As part of the implementation of the GC decision, UNEP established a Global Mercury Assessment Working Group, consisting of members nominated by Governments, intergovernmental organizations and non-governmental organizations.

In December 2002, a few months after AMAP published its second report on hazardous chemicals in the Arctic, UNEP published its first Global Mercury Assessment (GMA-02), a report that would play an essential role regarding the development of international cooperation on mercury. ${ }^{41}$ Although AMAP is not acknowledged as a direct contributor to the report, the assessment includes a vast number of references to AMAP reports, including the 1998 "Assessment report: Arctic Pollution Issues" and the 2000/2002 "AMAP report on issues of concern", ${ }^{42}$ as well as several figures developed by AMAP. ${ }^{43}$ In addition, numerous scientific studies developed by researchers linked to AMAP, are cited in the assessment. ${ }^{44}$

At the subsequent GC meeting in Nairobi in February 2003, it was agreed that there was sufficient evidence of significant global adverse impacts posed by mercury to warrant further international action. ${ }^{45}$ It was at this meeting that Norway and Switzerland, with the support of the EU, the African group and some LatinAmerican countries, proposed to start negotiating a legally binding instrument on mercury. However, agreement on such a mandate could not be met at the GCmeeting, and some delegates still called for more scientific work.

Speaking on behalf of Senior Arctic Officials of the AC, the Icelandic representative followed up the Arctic perspective addressed in the AMAP-reports by drawing attention to Arctic indigenous peoples and their risk of exposure to mercury through diet and its potential effects on neuro-development. ${ }^{46}$ Hence, discussions on developing a global framework were kept warm and UNEP was requested to compile Governments' views on future actions on mercury and present them at the GC's $23^{\text {rd }}$ session, for the purpose of deciding "on the possibility of developing a legally binding instrument, a non-legally binding instrument or other measures or actions." ${ }^{47}$

\subsubsection{3-2009}

At the $23^{\text {rd }}$ session of the UNEP GC meeting, held in Nairobi in 2005, UNEP was requested to further develop UNEPs mercury program by developing a report on supply, trade and demand. The objective behind the report was to improve knowledge on use and sources, including products and processes, building on submissions from governments, the private sector and international organizations. ${ }^{48}$ Although the report, titled "Summary of supply, trade and demand information on mercury" contains a few references to specific ACAP reports, AMAP was apparently not involved in preparing the report. ${ }^{49}$ It was concluded that an assessment of long-term action 
measures was needed, such as a legally binding instrument or other collaborative frameworks, and should be prepared for the next session..$^{50}$

At the following meeting, its $24^{\text {th }}$ session in 2007, major steps were taken: the GC requested that UNEP make a global inventory of anthropogenic emissions of mercury to the atmosphere. The report was prepared in cooperation with the AMAP Secretariat, which coordinated compilation of the report. ${ }^{51}$ This move represented greater involvement by the AC in preparing key background data, not only as a broker of Arctic data, but now even contributing to global efforts to document the scale and character of the mercury problem. The Global Atmospheric Mercury Assessment was finalized in December 2008, providing a more solid knowledge base on the global distribution and contribution of emissions sources. ${ }^{52}$

At the $24^{\text {th }}$ session, it was also decided to establish an overarching framework for the Global Mercury Partnerships - a voluntary body, which would include members from governments, industry and civil society stakeholders, to address the mercury problem in key sectors on a global scale. ${ }^{53}$ Furthermore, it was also decided to establish an ad hoc open-ended working group (OEWG), consisting of governments and stakeholder representatives to consider options for enhanced voluntary measures and/or international legal instruments.

The following two OEWG-meetings (2007 Bangkok, 2008 Nairobi) that were set up to assess measures to address the global mercury problem, carried out thorough discussions on voluntary versus legal measures on mercury. ${ }^{54}$ Substantial intersessional tasks were undertaken by the Secretariat in the interim period, to carefully analyze all aspects of the two alternative tracks. At its second meeting the delegates agreed on one legally binding option and three voluntary options to be considered by the UNEP GC. At the GC meeting in Nairobi in February 2009, the GC somewhat surprisingly agreed to develop a legally binding agreement on mercury to reduce risks to human health and the environment. UNEP was requested to convene one OEWG meeting in 2009 and to set up an Intergovernmental Negotiating Committee (INC) that would commence in 2010 and finalize the negotiations by GC-27 in 2013.

Following up, a few months after the GC decision on a legally binding approach, AMAP released an important assessment. The report "Human Health in the Arctic" (June 2009) documented the presence of mercury and other pollutants in the Arctic and illuminated the risk of effects on human health, especially on fetuses and young children, even at low levels. ${ }^{55}$ The report came with an explicit recommendation from AMAP to support the development of a global agreement "to limit mercury emissions to complement regional and national efforts that reduce environmental levels and lower human exposure to mercury in the Arctic". ${ }^{56}$

Even though the decision to initiate negotiations had already been made (February), the report may have provided motivation for some of the delegates to complete negotiations and reach a high level of protection of human health and the environment. It is also probable that a draft report had been circulated among AC 


\section{Froukje Maria Platjouw, Eirik Hovland Steindal and Trude Borch}

member states some months prior to publication, which may have given some incentive to countries such as the United States and Canada to support the agreement, countries that just a few months before had been opposed to a legally binding agreement. It is however plausible that the political turn-around made by the US had a stronger influence on that decision than an additional contribution to the already quite significant knowledge base. ${ }^{57}$

In sum, the limited involvement of AMAP in the early phases of the negotiations around international action on mercury (prior to 2003), is coherent with statements made by Norwegian government officials who chose to go directly to UNEP in 2003, when they proposed a legally binding approach; thus, avoiding the risk of a slow down by those countries favoring a voluntary approach (Canada, US and Russia). Given these different preferences among the Arctic states, it is surprising that AMAP in this critical phase of the international negotiations under the GC, could take on such a proactive role, not only as a broker of Arctic science, but also as the central facilitator and knowledge supplier to the UNEP assessment reports. Interestingly, as with its first assessment report, AMAP received funding from the Nordic Council of Ministers to carry out this support to UNEP, ${ }^{58}$ indicating that the Nordic countries to an increasing extent, intentionally or unintentionally, made use of several routes of influence in the development of key knowledge.

\subsection{What to regulate and how comprehensively? (2010-2013)}

When the delegates met at the first International Negotiating Committee (INC) in Stockholm in 2010, they did so with a common understanding that the gravity of the mercury problem was sufficiently documented, and that the apparent way forward was a globally binding approach. Notwithstanding, delegates had diverging views on how such an instrument should be shaped, what areas it should cover and to which degree. In this regard, the different economic, technical and social capabilities among the countries would become one of the most complex issues to address.

Whereas scientific input during the 1990s and early 2000s focused on identifying and understanding the scale of the mercury problem, later studies and assessments increasingly focused on sources of emissions and releases. For instance, the UNEP/ AMAP 2008 report included a chapter on the geographic distribution of air emission sources, one chapter on types of sources (anthropogenic, natural and remobilization) and one on industrial sources. ${ }^{59}$ Similarly, the AMAP report on human health from 2009 reviewed local sectoral sources of contaminants. ${ }^{60}$ Even though no agreement had been made at this point, the increasing focus on sources was not surprising, considering the fact that discussions on whether they should opt for a binding approach or not were coming closer to an end, and they were already addressing the details of what such an instrument would include. Within the UNECE-region and nationally in many countries, reduction measures had already been implemented over the last two-three decades, and there was substantial evidence to lean on. 
From Arctic Science to International Law

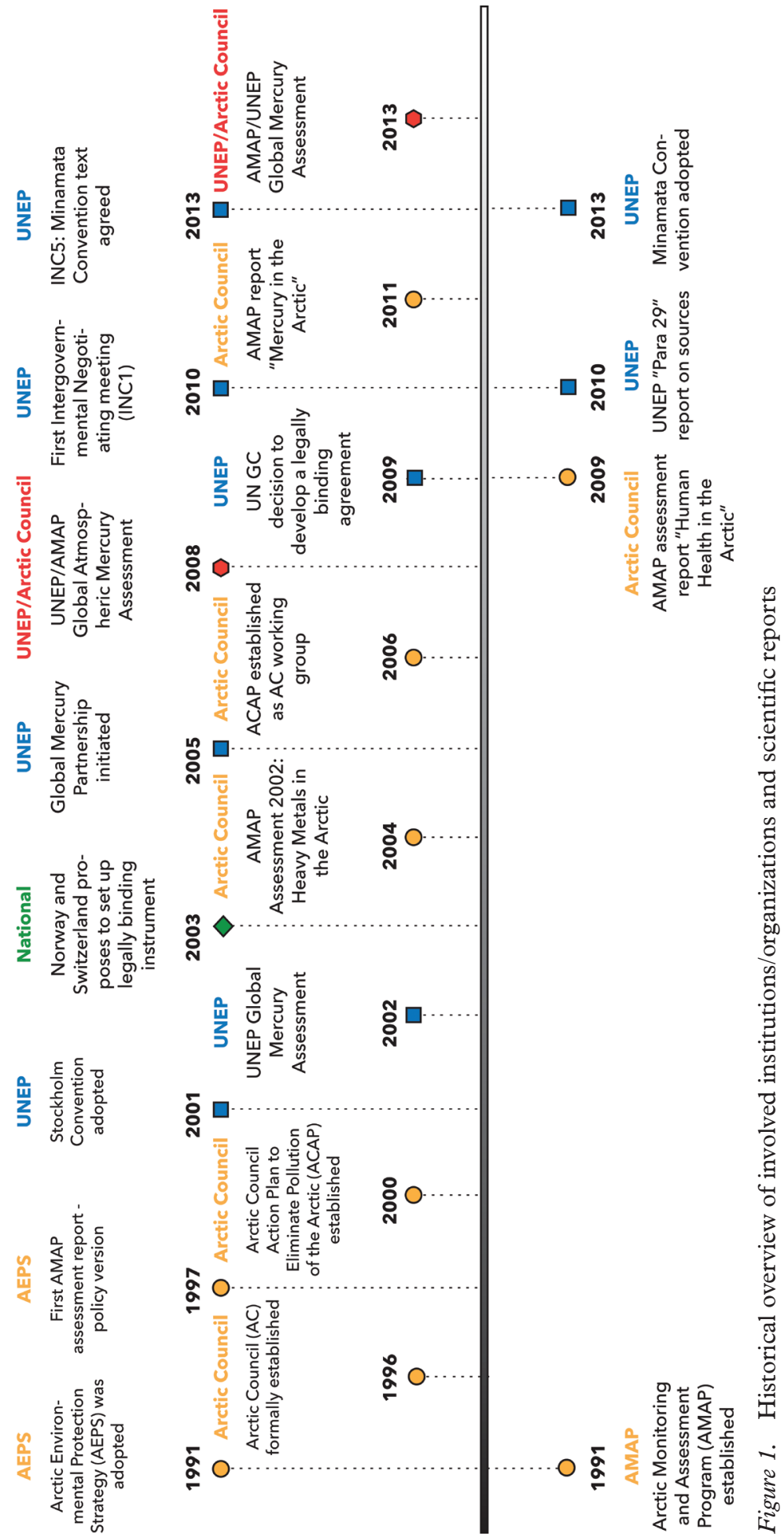




\section{Froukje Maria Platjouw, Eirik Hovland Steindal and Trude Borch}

Between 2010 and 2013 five INC meetings were arranged to develop an instrument based on consensus between the negotiating countries. During this period there were three assessments; AMAP had its stamp on all of them: The "UNEP Paragraph 29 study", the AMAP report "Mercury in the Arctic" and the UNEP "Global Mercury Assessment 2013".

As indicated above, already at the $25^{\text {th }}$ GC meeting in February 2009, the Governing Council requested that UNEP carry out a study of mercury-emitting sources, including an assessment of costs and effectiveness of control technologies and measures. ${ }^{61}$ The purpose was to "inform" the work of the INC and provide relevant information on appropriate control measures that could be featured in the instrument. The study was sponsored by the Nordic Council of Ministers and partly authored by AMAP-staff and researchers with close links to AMAP.Titled the "UNEP Paragraph 29 study", it became an important scientific document underpinning the importance of controlling key emitting sectors. In addition, the report was published at a critical stage. During the first meetings several important decisions were made on the structure and content of the convention. One of these decisions was which emission sources to air or product categories ought to be covered by the convention, another was whether to opt for a "negative" or a "positive" list of products. A "negative" list would imply that all use of all mercury-containing products is prohibited, unless explicitly exempted, whereas a positive list - which turned out to be the final decision - implies that all use is allowed, unless specifically banned.

The AMAP report "Mercury in the Arctic", published approximately a year later (2011) focused specifically on the challenges associated with mercury pollution in the Arctic. Besides emphasizing the need for more knowledge in the "policy-relevant science recommendation", the authors recommended that the AC continue to support the then on-going INC-process. The AMAP report is heavily cited in the AMAP/UNEP Global Mercury Assessment, published in June 2013 (GMA13).

The GMA13 report was a deliverable at the request of the GC in 2009 to update the GMA report from 2008. However, since it was published five months after the INC had agreed on a convention text (January 2013), it probably had a limited impact on the development of the Convention. ${ }^{62}$ An important purpose of the GMA13 was thus to update the knowledge-base on mercury use, emissions and management, and possibly represent a baseline for future action. Furthermore, even though the Convention text had been adopted, the report was still relevant for further work in the interim-period and the INC6 and INC7 meetings, where guidance documents, thresholds and other supporting material were to be developed.

\section{Conclusion}

This paper has shed light on the dynamic road towards the Minamata Convention through analyzing the role of AMAP, and the AC more generally, as a provider, broker and communicator of science related to the environmental problem of mercury. AMAP 
has played a key role in the process leading up to international negotiations on the Minamata Convention. To explain the success behind this process, three issues should be highlighted: the role of experts, the importance of timing, and the issue of funding.

Experts in AMAP had worked on the problem of mercury and its effects on human and environmental health for a long time before the adoption of the Minamata Convention in 2013. This pool of expertise linked to AMAP resulted in comprehensive scientific reports that increased awareness among stakeholders and enhanced scientific evidence on the adverse effects of mercury. Our analysis shows that AMAP researchers over the years and to an increasing extent have been involved in and contributed to important UNEP reports and assessments on mercury. This cooperation between AMAP and UNEP enhanced the strength of scientific evidence, whereby the severity of the environmental issue and the urgency of drafting a global legal instrument were clearly reinforced. The existence of a sound scientific evidence base affected the international negotiating process positively as resources could be used on negotiating legal approaches to reduce the use and release of mercury, rather than on disputing the scientific aspects of mercury.

When assessing the influence of AC on the establishment of the Minamata Convention, it is evident that good timing was a crucial factor in the science-policy interface. The acute nature of the environmental crisis gave a sense of urgency to the development of knowledge on which to base action. ${ }^{63}$ Important AMAP reports were released at important moments, increasing the weight of evidence on the problem of mercury, thus constructing the momentum and enhancing incentives for states to agree on the need to draft a legally binding instrument and to agree on different provisions of the Minamata Convention. The importance of good timing and the underlying intention to contribute to policy development is well illustrated by the release of the 1997 policy-format report 'Arctic Pollution Issues: A State of the Arctic Environment', one year before the release of its full technical and scientific version. This kind of policy-oriented scientific advice has played a strategically important role in the process. Due to its well-timed and thorough scientific reports on mercury, AMAP became increasingly more involved in the process. Although Norway had been reluctant to go through the AC when initiating the Convention in 2003, arguing that several of its member states were opposed to legally binding measures, the AC was increasingly used as an instrument for policy development on the global arena. In 2007, at the $24^{\text {th }}$ session, it was even decided that AMAP should coordinate the Global Atmospheric Mercury Assessment.

A final issue that should be highlighted is the significance of funding. An important factor affecting the intersection between science and policy is related to scientific orientation and funding. Not only does this impact on the topics science focuses on, but it also has an enormous effect on the way science proceeds and, to the extent that funding agencies stress the importance of dissemination, on the way scientific knowledge diffuses into society in general and into policy processes in particular. ${ }^{64} \mathrm{On}$ several occasions, the Nordic Council of Ministers funded scientific research carried out 


\section{Froukje Maria Platjouw, Eirik Hovland Steindal and Trude Borch}

by AMAP and by researchers related to AMAP. The first AMAP assessment report (1997-1998) was sponsored by the Nordic Council of Ministers. AMAP also received funding from the Council to contribute to the 2009 report on 'Human Health in the Arctic'.

In conclusion, the Arctic Council, through AMAP, has been a crucial supplier, knowledge provider and broker in the establishment of the Minamata Convention. However, the extent to which this is the result of strategic planning from member states or the AMAP secretary - or rather the result of organic development in line with global policy development on mercury remains an open question.

\section{ACKNOWLEDGEMENT}

The present study was funded through the Fram Centre flagship "Hazardous Substances-Effects on Ecosystems and Health." We are grateful for their funding.

\section{NOTES}

1. Minamata Convention on Mercury (opened for signature 19 January 2013, entered into force 16 August 2017), preamble para 1.

2. AMAP, 2011. Arctic Pollution 2011. Arctic Monitoring and Assessment Programme (AMAP), Oslo, p. 2.

3. Ibid.

4. Ibid.

5. Ibid, pp. 8-9.

6. On the issue of mercury chemistry in the air, the 2008 Global Atmospheric Mercury Assessment by UNEP clarified that levels of reactive gaseous mercury concentrations in the Arctic can on occasion by five to fifty times higher than levels measured in Europe and North-America. UNEP Chemicals Branch, 2008, The Global Atmospheric Mercury Assessment: Sources, Emissions and Transport. UNEP-Chemicals 2008.

7. AMAP, 2011. Arctic Pollution 2011. Arctic Monitoring and Assessment Programme (AMAP), Oslo, p.20

8. Ibid, p.2.

9. The eight Arctic states are: Canada, Denmark, Finland, Iceland, Norway, Russia, Sweden, and the United States.

10. Arctic Council, 'The Arctic Council: a backgrounder', 3 January 2018, available at: http:// arctic-council.org/index.php/en/about-us

11. Minamata Convention on Mercury.

12. Minamata Convention on Mercury, Article 1.

13. Minamata Convention on Mercury.

14. David VanderZwaag, "The 2013 Minamata Convention and Protection of the Arctic Environment: Mercurial Promises and Challenges", China Oceans Law Review 2 (2015): 224-243.

15. Noelle E. Selin, "Global Change and Mercury Cycling: Challenges for Implementing a Global Mercury Treaty”, 201433 Environmental Toxicology and Chemistry 33(6) (2014): 1202; David VanderZwaag, "The 2013 Minamata Convention and Protection of the Arctic Environment: Mercurial Promises and Challenges” 2 (2015): 235. VanderZwaag mentions the following challenges amongst others: for mercury air emissions, no overall obligations 
exist to reduce emissions but only to control emissions. For new sources, application of best available techniques and best environmental practices will be required, but guidance on best available techniques and best environmental practices was left to be adopted at the first meeting of the Conference of the Parties, and emission reduction is only required "when feasible". For existing sources, each Party is required to take at least one control measure but there is substantial discretion allowed in implementation as a Party may take into account its national circumstances and "the economic and technical feasibility and affordability of the measures." See Article 8 of the Minamata Convention.

16. See further VanderZwaag 2015.

17. Stephen Bocking, Nature's Experts: Science, Politics, and the Environment (Rutgers University Press, 2004).

18. Ibid.

19. Peter Gluckman, “The science-policy interface”, Science 353(6303) (2016): 969.

20. The EUREX study of policy processes in commissions in the Europe concludes that there is a high level of expertisation ${ }^{15}$. Not only were chairs and members increasingly scientific experts, there was also an increase in the number of citations of academic research in commission reports.

21. Pita Spruijt et al, "Differences in views of experts about their role in particulate matter policy advice: Empirical evidence from an international expert consultation", Environmental Science E Policy 59 (2016): 44-52; Several scholars have theoretically described how experts cope differently with this role, see for instance Roger A Pielke, The honest broker. Making sense of Science in Policy and Politics, (Cambridge University Press, 2007).

22. Roger A Pielke, The honest broker. Making sense of Science in Policy and Politics (Cambridge University Press, 2007).

23. Pita Spruijt et al, "Differences in views of experts about their role in particulate matter policy advice: Empirical evidence from an international expert consultation", Environmental Science E Policy 59 (2016): 45.

24. Sybille Van den Hove, “A rationale for science-policy interfaces", Futures 39 (2017): 824.

25. Pita Spruijt et al, "Roles of scientists as policy advisors on complex issues: A literature review”, Environmental Science \&o Policy 40 (2014): 22.

26. Donald Rothwell, The Polar Regions and the Development of International Law (Cambridge: Cambridge University Press, 1996): 231-233.

27. Arctic Environment, Arctic Environmental Protection Strategy, 14 June 1991. Available at $<$ http://library.arcticportal.org/1542/1/artic_environment.pdf $>$. see also Bruce A Russell, "The Arctic Environmental Protection Strategy \& the New Arctic Council", available at $<$ http://arcticcircle.uconn.edu/NatResources/Policy/uspolicy1.html>.

28. UNEP Chemicals, "Global Mercury Assessment", December 2002, available at <http:// wedocs.unep.org/bitstream/handle/20.500.11822/11718/final-assessment-report-5nov02. pdf?sequence $=1$ \&isAllowed $=\mathrm{y}>$

29. Arctic Council, "Declaration on the establishment of the Arctic Council. Joint communique of the governments of the Arctic countries on the establishment of the Arctic Council", 19 September 1996. Available at <https://oaarchive.arctic-council.org/bitstream/handle/ 11374/85/EDOCS-1752-v2-ACMMCA00_Ottawa_1996_Founding_Declaration.PDF?sequence $=5 \&$ isAllowed $=\mathrm{y}>$

30. Interestingly, it is stated in the first AMAP report that it was not formally integrated as a working group before the Ministerial Conference in 1997, at which the AMAP assessment was presented, and when the responsibility for the AEPS officially was transferred to the newly established Arctic Council.

31. The assessment was made possible through financial support from the member states, as well as designated funds from the Nordic Council of Ministers, and the United Nations Environment Program (UNEP). 


\section{Froukje Maria Platjouw, Eirik Hovland Steindal and Trude Borch}

32. During this time AMAP had also ventured into cooperation with the Nordic Council of Ministers and the EMEP on air transport and modelling of mercury and POPs. AMAP, 2005, "AMAP Assessment 2002: Heavy Metals in the Arctic. Arctic Monitoring and Assessment Programme (AMAP)", Oslo, Norway. (first published as an electronic document in 2004).

33. This was the "Arctic Council Action Plan", not to be confused with the "Arctic Council Action Program", that was established as a working group in 2006. https://oaarchive.arctic-council.org/handle/11374/1

34. AMAP, "Arctic Pollution 2002: Persistent Organic Pollutants, Heavy Metals, Radioactivity, Human Health, Changing Pathways" Arctic Monitoring and Assessment Programme (AMAP) 2002, Oslo, Norway. xii+112 pp. Available at <https://www.amap.no/documents/ doc/arctic-pollution-2002/69>.

35. Timo Koivurova, Paula Kankaanpää and Adam Stępién, "Innovative Environmental Protection: Lessons from the Arctic", fournal of Environmental Law 27 (2015): 293.

36. Koivurova et al (2015): 297.

37. Arctic Council (2016). Arctic Resilience Report. Marcus Carson and Garry Peterson (eds). Stockholm Environment Institute and Stockholm Resilience Centre: 137.

38. Svein Vigeland Rottem, "The Use of Arctic Science: POPs, the Stockholm Convention and Norway" Arctic Review on Law and Politics 8 (2017): 263.

39. Henrik Hallgrim Eriksen and Franz Xaver Perrez, "The Minamata Convention: A Comprehensive Response to a Global Problem", RECIEL 23 (2) (2014): 196

40. The assessment should be carried out in cooperation with other members of the Inter-Organization Program for the Sound Management of Chemicals (IOMC); a cooperative agreement among UNEP, ILO, FAO, WHO, UNIDO, UNITAR and OECD.

41. UNEP Chemicals, "Global Mercury Assessment", December 2002, available at <http:// wedocs.unep.org/bitstream/handle/20.500.11822/11718/final-assessment-report-5nov02. pdf? sequence $=1$ \&isAllowed $=y>$

42. To the best of our knowledge, this 2000-report was an early draft of the 2002 AMAP State of the Art report described above.

43. AMAP (1998) "Assessment report: Arctic Pollution Issues. Arctic Monitoring and Assessment Programme”, Oslo, 1998. AMAP (2000), “AMAP report on issues of concern: Updated information on human health, persistent organic pollutants, radioactivity, and mercury in the Arctic". AMAP Report 2000:4, found on www.amap.no.

44. AMAP, 2005. "AMAP Assessment 2002: Heavy Metals in the Arctic. Arctic Monitoring and Assessment Programme (AMAP)", Oslo, Norway. xvi +265 pp. (first published as electronic document in 2004). Available at <https:/oaarchive.arctic-council.org/bitstream/ handle/11374/706/aar2002-HeavyMetals.pdf.pdf?sequence $=1$ \&isAllowed=y $>$

45. UNEP, At a Glance: Minamata Convention on Mercury, fact sheet, available at $>$ http://www. mercuryconvention.org/Portals/11/documents/Awareness\%20raising/FACT\%20SHEETS/ Minamata\%20Convention\%20on\%20Mercury\%20at\%20a\%20glance_COP1\%202017. pdf $>$

46. Governing Council of UNEP, Proceedings of the Governing Council/Global Environment Ministerial Forum at its twenty-second session, UNEP/GC.22/11, 21 February 2003, available at: http://wedocs.unep.org/bitstream/handle/20.500.11822/10645/K0360655-EGC22_Proceeding.pdf?sequence=1\&isAllowed=y

47. Ibid.

48. Earth Negotiations Bulletin, First Meeting of the Intergovernmental negotiating committee to prepare a global legally binding instrument on mercury: 7-11 JUNE 2010, Vol. 28 No. 6, 14 June 2010, available at: http://enb.iisd.org/download/pdf/enb2806e.pdf; the entire report "Summary of supply, trade and demand information on mercury", November 2006 is accessible at: https://wedocs.unep.org/bitstream/handle/20.500.11822/11610/HgSupplyTradeDemandJM.pdf? sequence $=1$ \&isAllowed $=y$ 
49. UNEP report "Summary of supply, trade and demand information on mercury", November 2006. Accessible at: https://wedocs.unep.org/bitstream/handle/20.500.11822/11610/ HgSupplyTradeDemandJM.pdf?sequence=1\&isAllowed=y

50. Governing Council of UNEP, Proceedings of the Governing Council/Global Environment Ministerial Forum at its twenty-third session, UNEP/GC.23/11, 7 April 2005, available at: http://wedocs.unep.org/bitstream/handle/20.500.11822/10581/GC23_PROCEEDING_ ENGLISH.pdf?sequence $=1 \&$ isAllowed $=\mathrm{y}$

51. UNEP Chemicals branch 2008, "The Global Atmospheric Mercury Assessment: Sources, Emissions and Transport", UNEP-Chemicals, Geneva. Available at: https://wedocs.unep. org/bitstream/handle/20.500.11822/11517/UNEP_GlobalAtmosphericMercuryAssessment_May2009.pdf?sequence $=1$ \&isAllowed $=\mathrm{y}$

52. Ibid.

53. United Nations Governing Council, Twenty-fourth session of the Governing Council/Global Ministerial Environment, Nairobi, 5-9 February 2007, UNEP/GC/24/12, 19 February 2007, document available at: http://wedocs.unep.org/bitstream/handle/20.500.11822/10624/K076 0630_GC24-proceedings.pdf?sequence=1\&isAllowed=y

54. Earth Negotiations Bulletin, First Meeting of the Intergovernmental negotiating committee to prepare a global legally binding instrument on mercury: 7-11 JUNE 2010, Vol. 28 No. 6 , 14 June 2010, available at: http://enb.iisd.org/download/pdf/enb2806e.pdf.

55. AMAP, 2009. AMAP Assessment 2009: Human Health in the Arctic. Arctic Monitoring and Assessment Programme (AMAP), Oslo, Norway. xiv+254 pp. Available at: https://www. amap.no/documents/doc/amap-assessment-2009-human-health-in-the-arctic/98

56. The report was sponsored by the Nordic Council of Ministers.

57. The US position changed rather abruptly in when the Obama administration took office in 2009: See also: Steinar Andresen, Kristin Rosendal and Jon Birger Skjærseth, "Why Negotiate a Legally Binding Mercury Convention?", International Environmental Agreements 13 (4) (2013).

58. AMAP, 2009. "AMAP Assessment 2009: Human Health in the Arctic. Arctic Monitoring and Assessment Programme (AMAP)", Oslo, Norway. xiv+254 pp. Available at: https:// www.amap.no/documents/doc/amap-assessment-2009-human-health-in-the-arctic/98

59. NordicEnvironment, 'Mercury - Nordic countries show the way to a global agreement', May 2010, available at: http://www.norden.org/en/nordmiljoe/special-issues/2010/mercury2013-nordic-countries-show-the-way-to-a-global-agreement-1/

60. AMAP, 2009. AMAP Assessment 2009: Human Health in the Arctic. Arctic Monitoring and Assessment Programme (AMAP)", Oslo, Norway. xiv+254 pp. Available at: https://www. amap.no/documents/doc/amap-assessment-2009-human-health-in-the-arctic/98

61. UNEP, Division of Technology, Industry and Economics (DTIE) Chemicals Branch, Geneva, Switzerland, November, 2010, "Study on mercury sources and emissions, and analysis of cost and effectiveness of control measures "UNEP Paragraph 29 study"”, available at: https://wedocs.unep.org/bitstream/handle/20.500.11822/11713/Final_Report_Para29_5_ Nov_2010.pdf?sequence $=1 \&$ isAllowed=y

62. Due to the fact that GMA-drafts are circulated nearly a year in advance it cannot be ruled out that the information was used actively in the negotiations, however, since such drafts are not "citable" and the development of the convention had come so far, we consider it a rather unlikely scenario.

63. Sybille Van den Hove, "A rationale for science-policy interfaces”, 39 Futures (2007): 818.

64. Van den Hove (2007): 812. 